2016 - Volume: 5 Number: 1

Page: $37-45$

DOI : $10.18036 /$ btdc. 78679

Received: 24 March 2016

Revised: 18 June 2016

Accepted: 24 July 2016

\title{
COMPARISON OF RESISTANCE RATES AND DETECTION OF FIVE RESISTANCE GENES (BTS) IN TEN LOCAL WHEAT VARIETIES AGAINST COMMON BUNT DISEASE
}

\author{
İsmail POYRAZ ${ }^{1, *}$, Nurcan GÜMÜŞ ${ }^{1}$ \\ ${ }^{1}$ Department of Molecular Biology and Genetic, Faculty of Art \& Science, Bilecik Şeyh Edebali University, \\ 11210, Bilecik, Turkey.
}

\begin{abstract}
Common bunt caused by Tilletia $s p$. is a very destructive and dangerous seed-borne fungal disease and may cause serious economic losses in worldwide. Wheat cultivars carrying resistance genes are used as an alternative fight method instead of chemical fungicides against common bunt disease. These resistance genes in wheat are called as $b t$ genes. Until today, a few number of $b t$ genes has been detected in wheat by using various molecular markers. However, development of more molecular markers for detection of all $b t$ genes in wheat is required. In this study, detection of five $b t$ genes called as $b t-5, b t$ $8, b t-10, b t-11$ and $b t-12$ was carried in ten registered local wheat varieties (Sertak 52, Bolal 2973, Demir, Kutluk, Harmankaya 99, Pehlivan, Tosun Bey, 4-11, Sönmez 01, Bezostaja-1) using PCR-based molecular markers, microsatellite and RAPD. PCR-amplified fragments were separated on $1.3 \%$ agarose gel. The obtained DNA bands were scored as present or absent for detection of $b t$ genes. For comparison, the virulence rates of five Tilletia foetida (syn. leaves) isolates against ten wheat varieties were obtained from our field results. We observed that wheat varieties Kutluk and 4-11 carrying $b t-10$ and bt11 genes are more resistant to disease in field.
\end{abstract}

Keywords: Common bunt, Wheat, $B t$ resistance genes, Molecular markers

\section{ON BUĞDAY ÇEŞIDINDE SÜRMEYE KARŞI BAZI DİRENÇ GENLERİNIN (BT-5, BT-8, BT-10, BT-11 VE BT-12) MOLEKÜLER MARKÖRLER KULLANILARAK TESPITI}

\begin{abstract}
ÖZET
Sürme (Tilletia sp.) buğdayda çok tehlikeli bir tohum hastalığıdır ve ciddi ekonomik kayıplara neden olabilir. Direnç genleri içeren buğday kültürleri, sürme hastalığına karşı mücadelede fungusidlerin yerine alternatif bir mücadele yöntemidir. Buğdaydaki bu direnç genleri $b t$ genleri olarak adlandırılır. Bugüne kadar buğdayda $b t$ genlerinin çok az bir kısmı bazı moleküler markörler ile tespit edilmiştir. Buğdayda tüm $b t$ genlerinin tespiti için geliştirilmiş moleküler markörler bulunmamaktadır. Bu çalışmada, PCR tabanlı moleküler markörler (Mikrosatellit ve RAPD) kullanılarak tescilli 10 buğday çeşidinde (Sertak 52, Bolal 2973, Demir, Kutluk, Harmankaya 99, Pehlivan, Tosun Bey, 4-11, Sönmez 01, Bezostaja-1) bazı $b t$ genlerinin $(b t-5, b t-8, b t-10, b t-11$ and $b t-12)$ tespiti gerçekleştirilmiştir. PCR ile çoğaltılan fragmentler, ethidium bromide $(0.5 \mu \mathrm{g} / \mathrm{ml})$ içeren \% 1.3 'lük agaroz jelde ayrılmıştır. Jeller UV ışık altında gözlenmiş ve dijital olarak fotoğraflanmıştır. Elde edilen DNA bantları bt genleri için var veya yok olarak değerlendirilmiştir. Karşılaştırma yapmak için, 10 buğday çeşidine karşı beş Tilletia foetida (syn. leaves) izolatının hastalık yapma oranı tarla verilerinden elde edilmiştir. Kutluk ve 4-11 gibi bt10 ve btl1 genlerini içeren buğday çeşitlerin tarlada hastalığa karşı daha dirençli oldukları gözlenmiştir. Tüm buğday çeşitlerindeki beş $b t$ geni için analiz sonuçları ve tarladaki direnç oranlarını gösterilmiştir.
\end{abstract}

Anahtar Kelimeler: Buğday, Bt direnç genleri, Sürme, Moleküler markörler

\section{INTRODUCTION}

Common bunt is the major seedborne disease posing a threat to wheat production. It is caused by two closely related fungi, Tilletia caries (D.C.) Tul. \& C. Tul. [syn. T. tritici (Bjerk.) G. Winter] and T. laevis J.G. Kühn [syn. T. foetida (Wallr.) Liro] [1-2]. This disease has been observed in different areas such as Western Asia, North Africa, Canada, United States and United Kingdom [1,3]. The disease is still a major problem, especially in North Africa and West Asia [3-5]. Recent bunt outbreaks, 
contamination especially with $T$. foetida and $T$. caries spores of wheat has become a problem resulting in losses in yield and seed quality [1, 5-6]. Common bunt is easily controlled by chemical seed treatments, and has reduced the disease to an insignificant problem in worldwide, but the disease continues to cause serious losses in areas of North Africa and West Asia [1-2, 4-5, 7]. In past decades, resistance to bunt was not important for traditionalist breeders and farmers due to the availability of effective chemical treatments in conventional farming [5]. In organic farming, where the use of synthetic chemicals is not allowed, seed-borne diseases tend to accumulate and may become a problem after several multiplication cycles without adequate disease [5]. In western countries, expanding environmental awareness and interest in organic farming demand a reduction in chemical seed treatment and there is a need for alternative tools for control of plant diseases such as common bunt. A number of resistance genes effective against common bunt fungi have been identified [8-10] and are widely deployed in North American cultivars of wheat. In Europe, little is known about common bunt resistance in modern high yielding wheat cultivars and extensive screening programs have consequently been initiated in several countries [4]. There is a classic gene-for-gene relationship between virulence genes of the bunt pathogen and the many known wheat resistance-genes. Resistance is controlled by major genes that interact with the genes of specific pathogenic races. Pathogenic races are genetic variants of the same species and can be distinguished by their ability to attack host genotypes with different resistance genes. Thus, the expression of resistance or susceptibility of a wheat cultivar depends on the pathogenic race attacking it [1]. Virulence of these fungi is regulated by the same set of bunt resistance genes in wheat [8]. The gene-for-gene interaction between pathogen bunt and host wheat accounts for the non-durable resistance of most cultivars. Resistance genes in wheat served to select the virulent types from the pathogen population [9]. These resistance genes are named $b t$ and include fifteen genes (bt1-bt15) [1, 10]. The availability of the microsatellite markers (SSRs) transmitted in linkage with some common bunt resistance genes could accelerate the process of breeding and selection. The some RAPD (Random Amplification of Polymorphic DNA) [11] and SSRs markers molecular markers for some common bunt resistance genes have been identified until today [12-13]. The SSR markers are the most frequently used for wheat owing mainly to their high polymorphism [14]. The use of partially or fully resistant wheat cultivars is another important bunt protection strategy besides of fungicide treatments. However, due to the availability of effective chemical treatments, resistance to bunt was not important for breeders and farmers in past decades [5]. The disease has re-emerged and has caused enormous yield losses, especially when susceptible cultivars have been grown [1].

The aim of this study was to detect some $b t$ genes ( $b t-5, b t-8, b t-10, b t-11$ and $b t-12)$ in ten registered local wheat varieties using PCR markers (microsatellite-SSR and RAPD) developed for these wheat varieties.

\section{MATERIALS AND METHODS}

\subsection{Materials}

Five T. foetida isolates (Table 1) and ten registered local wheat varieties (Table 2) were provided from Transitional Zone Agricultural Research Institute (Eskişehir, Turkey). Each T. foetida isolate was isolated from wheat variety in different locations and fields (Table 1).

Table 1. T. foetida isolates, their geographic origin and host wheat varieties

\begin{tabular}{|l|l|l|l|}
\hline Isolate No & Pathogen & Geographic Origin & Host Wheat Variety \\
\hline Isolate 1 & T. foetida & Tozman Plateau Düden Location & Kirkambar Awnless \\
\hline Isolate 2 & T. foetida & Tozman Plateau Düden Location & Kirg1z \\
\hline Isolate 3 & T. foetida & Kavac1k Village & Gerek-Kırg1z-A \\
\hline Isolate 4 & T. foetida & Kavac1k Village & Gerek-Kırg1z-B \\
\hline Isolate 5 & T. foetida & Transitional Zone Agricultural Research Institute Test Field & Gerek \\
\hline
\end{tabular}


Table 2. Wheat varieties, their characteristics and resistance

\begin{tabular}{|l|c|c|}
\hline \multicolumn{1}{|c|}{ Used Wheat Varieties } & Characteristics & $\begin{array}{c}\text { Resistance According to } \\
\text { Literature [14-15] }\end{array}$ \\
\hline Sertak 52 & Wintery & Unknown \\
\hline Bolal 2973 & Wintery & Sensitive \\
\hline Demir & Wintery & Sensitive \\
\hline Kutluk & Wintery & Resistant \\
\hline Harmankaya 99 & Wintery & Resistant \\
\hline Pehlivan & Wintery & Sensitive \\
\hline Tosun Bey & Wintery & Sensitive \\
\hline $4-11$ & Wintery & Unknown \\
\hline Sönmez 01 & Wintery & Resistant \\
\hline Bezostaja-1 & Wintery & Semi-Resistant \\
\hline
\end{tabular}

\subsection{Field Studies}

Ten wheat varieties were contaminated with five $T$. foetida isolates and grown in field (Bilecik, Turkey). Then, virulence rates of all isolates against wheat varieties were determined with field studies. The grown wheat varieties were freshly collected from field and stored at $-20^{\circ} \mathrm{C}$ before DNA isolation.

\subsection{DNA Isolation and PCR Amplifications}

DNA extraction was performed using the CTAB procedure with minor modifications [15]. Microsatellite primers and RAPD primers were used in PCR amplifications for detection of $b t$ genes. Microsatellite primers: Xgwm469 (bt10) (Forward primer: CAA CTC AGT GCT CAC ACA ACG; Reverse primer: CGA TAA CCA CTC ATC CAC ACC). Xgwm114 (bt8, bt10 and bt11) (Forward primer: ACA AAC AGA AAA TCA AAA CCCG; Reverse primer: ATC CAT CGC CAT TGG AGTG). Xgwm264 (bt12) (Forward primer: GAG AAA CAT GCC GAA CAA CA; Reverse primer: GCA TGC ATG AGA ATA GGA ACTG). Xgwm374 (bt12) (Forward primer: ATA GTG TGT TGC ATG CTG TGTG; Reverse primer: TCT AAT TAG CGT TGG CTG CC). RAPD primers: UBC196 (bt10) (CTC CTC CCCC).

PCR amplification for microsatellite primers was carried out in a total reaction volume of $25 \mu \mathrm{l}$ containing $10 \mathrm{ng}$ of template DNA, $1 \mathrm{X}$ Taq polymerase reaction buffer, $2 \mathrm{~mm} \mathrm{MgCl}_{2}, 0.1 \mathrm{~mm}$ each of dNTPs (dATP, dCTP, dGTP, and dTTP), $0.2 \mathrm{mM}$ primer and $1 \mathrm{U}$ of Taq DNA polymerase (Fermentas). Amplifications were performed in a Techne TC Plus thermocycler (Techne Inc.) programmed as follows: 4 min denaturation at $94{ }^{\circ} \mathrm{C}$ and 45 cycles of $45 \mathrm{sec}$. each denaturation at 94 ${ }^{\circ} \mathrm{C}$, $50 \mathrm{sec}$ annealing at $45-60{ }^{\circ} \mathrm{C}$ for ISSR amplification, and a $1.5 \mathrm{~min}$ extension at $72{ }^{\circ} \mathrm{C}$, followed by a final extension at $72{ }^{\circ} \mathrm{C}$ for $7 \mathrm{~min}$.

PCR amplification for RAPD primers was performed in $25 \mu$ of reaction mixture containing $15 \mathrm{ng}$ of template DNA, 1X Taq polymerase buffer and $1 \mathrm{U}$ of Taq polymerase (Fermentas, USA), $2.0 \mathrm{mM}$ $\mathrm{MgCl}_{2}, 1 \mathrm{mM} \mathrm{dNTP}$, and $1 \mu \mathrm{M}$ of primer. Amplifications were carried out in a Techne TC Plus thermocycler (Techne Inc., UK) that was programmed for the initial denaturation step $85^{\circ} \mathrm{C}$ for $15 \mathrm{sec}$. and at $92{ }^{\circ} \mathrm{C}$ for $2 \mathrm{~min}$, followed by 45 cycles of $94{ }^{\circ} \mathrm{C}$ for $1 \mathrm{~min}, 32-36{ }^{\circ} \mathrm{C}$ for $1 \mathrm{~min}, 72{ }^{\circ} \mathrm{C}$ for $2 \mathrm{~min}$, and a final elongation at $72{ }^{\circ} \mathrm{C}$ for $7 \mathrm{~min}$. Amplification products were separated on $1.3 \%$ agarose gel containing ethidium bromide $(0.5 \mu \mathrm{g} / \mathrm{ml})$. Gels were visualized under UV light and digitally photographed with Gel Logic 212Pro imaging system (Carestream, USA). Molecular weights of ISSR- 
PCR products were estimated using a 100 bp Plus DNA Ladder (Fermentas). PCR reactions for RAPD and ISSR primers were repeated twice to ensure reproducibility of amplified products.

\section{RESULTS}

We obtained virulence rates of five $T$. foetida isolates against ten wheat varieties (Table 3 ) and resistance of these wheat varieties from field studies (Table 4). Thus, we provide a comparison opportunity among resistance and virulence data from field studies and $b t$ genes data from PCR studies about this disease in selected wheat varieties According to our results, it was founded that the most effective isolate among five isolates is isolate 5. In addition, it was founded that the most resistant wheat varieties among ten varieties are Sönmez 01, Kutluk and Sertak52 (Tables 3 and 4).

Table 3. Virulence rates of five $T$. foetida isolates against ten wheat varieties

\begin{tabular}{|l|l|l|l|l|l|}
\hline & \multicolumn{5}{|c|}{ Virulence Rates (\%) } \\
\hline Wheat Varieties & Isolate-1 & Isolate-2 & Isolate-3 & Isolate-4 & Isolate-5 \\
\hline Sertak52 & 5.4 & 7.27 & 3.78 & 18.51 & 54.12 \\
\hline Bolal 2973 & 21.18 & 46.7 & 30.69 & 54.54 & 57.44 \\
\hline Demir & 25 & 38.39 & 51.92 & 46.66 & 60 \\
\hline Kutluk & 3.8 & 7.40 & 1.78 & 7 & 33.04 \\
\hline Harmankaya99 & 0.90 & 55.55 & 11.2 & 70.08 & 60.39 \\
\hline Pehlivan & 0 & 20 & 9.61 & 22.33 & 21.66 \\
\hline Tosun Bey & 0 & 10.71 & 64.28 & 58.67 & 72.72 \\
\hline 4-11 & 0.70 & 10 & 5.98 & 15.92 & 17.35 \\
\hline Sönmez 01 & 0.99 & 11.71 & 3.80 & 6.3 & 4.71 \\
\hline Bezostaja & 2 & 30.69 & 13.46 & 2.38 & 44.11 \\
\hline
\end{tabular}

Table 4. Resistance of ten wheat varieties against five $T$. foetida isolates

\begin{tabular}{|l|l|l|l|l|l|l|c|}
\hline \multicolumn{2}{|l}{} & Isolate-1 & Isolate-2 & Isolate-3 & Isolate-4 & Isolate-5 & $\begin{array}{c}\text { Resistance } \\
\text { According to } \\
\text { Literature [18-19] }\end{array}$ \\
\hline \multirow{2}{*}{} & Sertak52 & Resistant & Resistant & Resistant & Sensitive & Sensitive & Unknown \\
\cline { 2 - 8 } & Bolal 2973 & Sensitive & Sensitive & Sensitive & Sensitive & Sensitive & Sensitive \\
\cline { 2 - 8 } & Demir & Sensitive & Sensitive & Sensitive & Sensitive & Sensitive & Sensitive \\
\cline { 2 - 8 } & Kutluk & Resistant & Resistant & Resistant & Sensitive & Sensitive & Resistant \\
\cline { 2 - 8 } & Harmankaya99 & Resistant & Sensitive & Sensitive & Sensitive & Sensitive & Resistant \\
\cline { 2 - 8 } & Pehlivan & Resistant & Sensitive & Resistant & Sensitive & Sensitive & Sensitive \\
\cline { 2 - 8 } & Tosun Bey & Resistant & Sensitive & Sensitive & Sensitive & Sensitive & Sensitive \\
\cline { 2 - 8 } & 4-11 & Resistant & Sensitive & Resistant & Sensitive & Sensitive & Unknown \\
\cline { 2 - 7 } & Sönmez 01 & Resistant & Sensitive & Resistant & Resistant & Resistant & Resistant \\
\cline { 2 - 7 } & Bezostaja & Resistant & Sensitive & Sensitive & Sensitive & Sensitive & Resistant \\
\hline
\end{tabular}

We performed PCR amplifications for detection of $b t$ genes, using microsatellite and RAPD primers (Figure 1-5). It was obtained respectively $120 \mathrm{bp}, 160 \mathrm{bp}$ and $180 \mathrm{bp}$ bands for bt11, bt10 and bt8 using Xgwm 114 microsatellite primers (Figure 1). Similarly, Xgwm 264 primers amplified 190 bp band for $b t 12$, Xgwm 374 primers amplified 180 bp band for $b t 12$, Xgwm 469 primers amplified 165 bp band for $b t 10$ and UBC196 primer amplified 790 bp band for $b t 10$. 
Poyraz and Gümüş / Anadolu Univ. J. of Sci. and Technology-C-Life. Sci. and Biotech. 5 (1) - 2016

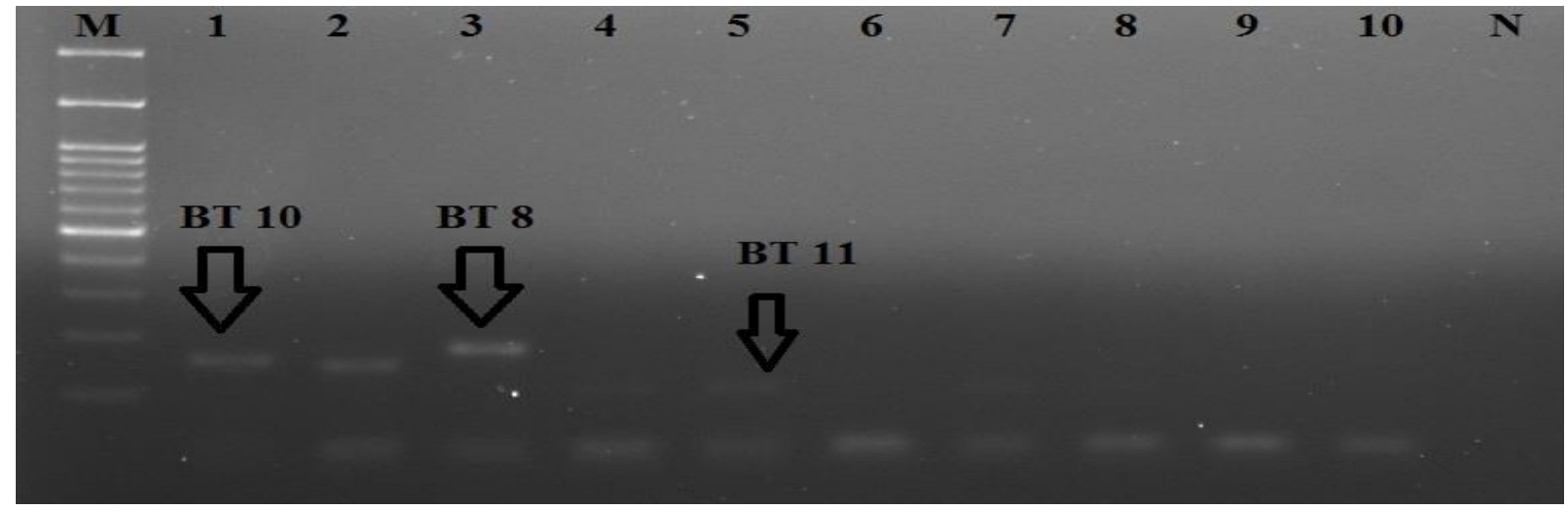

Figure 1. Agarose gel picture of amplified PCR products (respectively $120 \mathrm{bp}, 160 \mathrm{bp}$ and $180 \mathrm{bp}$ ) with Xgwm 114 primers for bt11, bt10 and bt8 genes. M: 100bp plus DNA ladder marker, 1-10: Wheat varieties, $\mathrm{N}$ : Negative control.

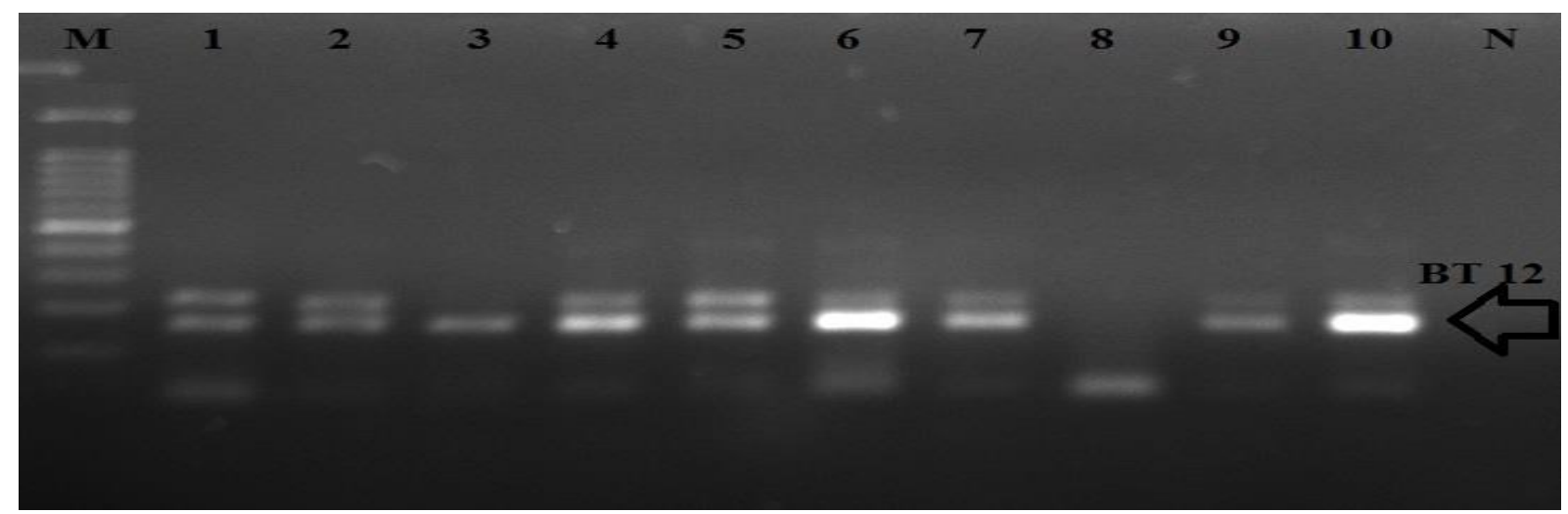

Figure 2. Agarose gel picture of amplified PCR products (190 bp) with Xgwm 264 primers for bt12 genes.

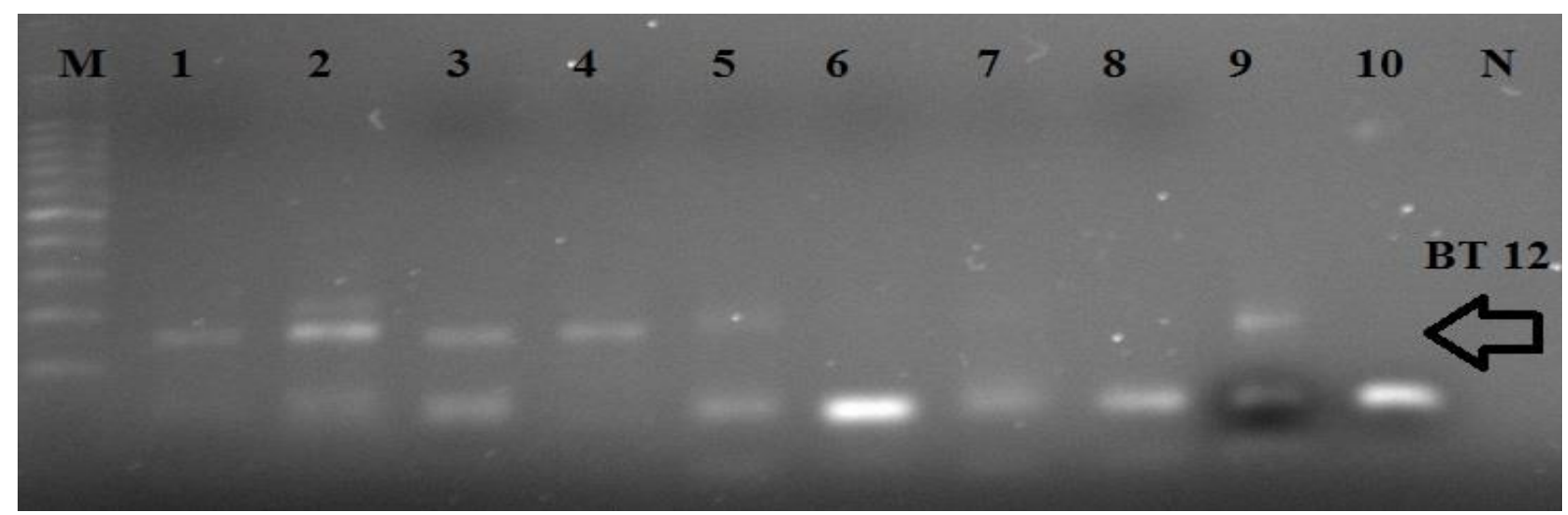

Figure 3. Agarose gel picture of amplified PCR products (180 bp) with Xgwm 374 primers for bt12 genes. 
Poyraz and Gümüş / Anadolu Univ. J. of Sci. and Technology-C-Life. Sci. and Biotech. 5 (1) - 2016

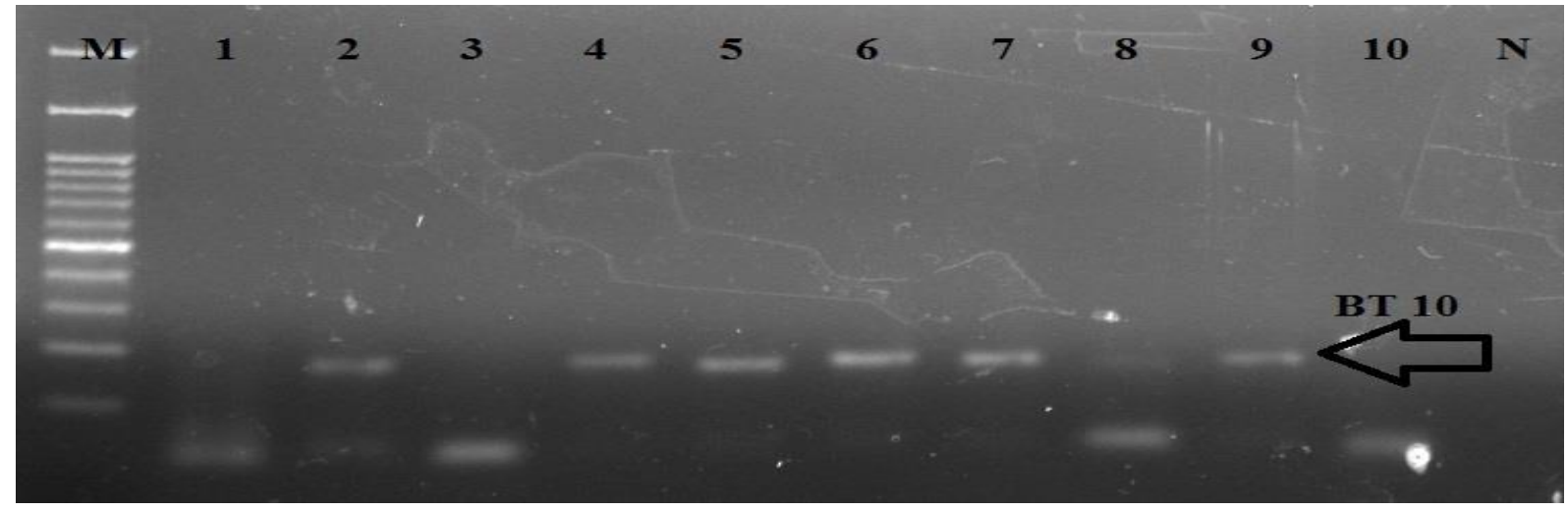

Figure 4. Agarose gel picture of amplified PCR products (165 bp) with Xgwm 469 primers for bt10 genes.

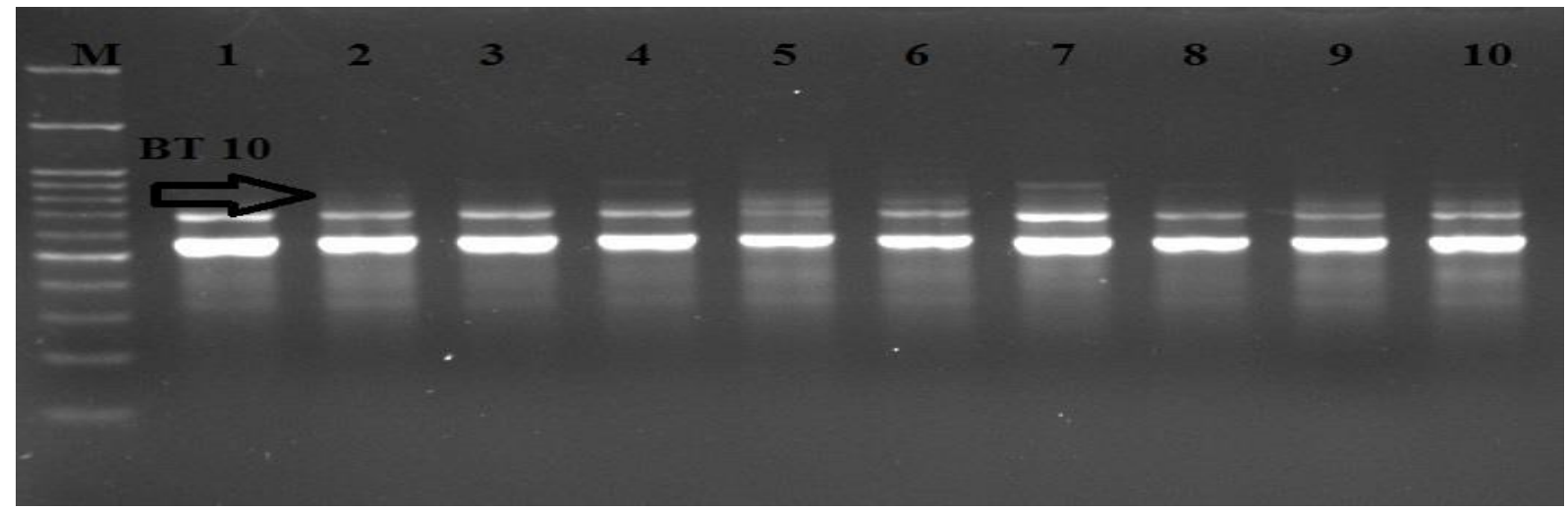

Figure 5. Agarose gel picture of amplified PCR products (790 bp) with UBC 196 primer for bt10 genes.

Results of PCR analyses were summarized in Table 5. It was seen that three wheat varieties, Kutluk, Harmankaya and Tosun Bey, contained bt-10, 11, and 12 genes. Demir contained bt-8, bt-10 and bt-12 genes. Sertak 52 and Bolal 2973 contained bt 10 and bt 12 genes, and Bezostaja contained only bt-10 gene. While bt-10 was observed in all varieties, Bt-5 gene was not seen in any wheat varieties studied.

Table 5. Determined resistance $(b t)$ genes of ten wheat varieties.

\begin{tabular}{|c|c|c|c|c|c|}
\hline Wheat Variety & bt 5 & bt 8 & bt 10 & bt 11 & bt 12 \\
\hline Sertak 52 & $\mathrm{X}$ & $\mathrm{X}$ & $\checkmark$ & $\mathrm{X}$ & $\checkmark$ \\
\hline Bolal 2973 & $\mathrm{X}$ & $\mathrm{X}$ & $\boldsymbol{V}$ & $\mathrm{X}$ & $\checkmark$ \\
\hline Demir & $\mathrm{X}$ & $\checkmark$ & $\checkmark$ & $\mathrm{X}$ & $\checkmark$ \\
\hline Kutluk & $\mathrm{X}$ & $\mathrm{X}$ & $\checkmark$ & $\checkmark$ & $\checkmark$ \\
\hline Harmankaya99 & $X$ & $\mathrm{X}$ & $\checkmark$ & $\checkmark$ & $\checkmark$ \\
\hline Pehlivan & $\mathrm{X}$ & $\mathrm{X}$ & $\checkmark$ & $\mathrm{X}$ & $\checkmark$ \\
\hline Tosun Bey & $\mathrm{X}$ & $\mathrm{X}$ & $\checkmark$ & $\checkmark$ & $\checkmark$ \\
\hline 4-11 & $\mathrm{X}$ & $\mathrm{X}$ & $\checkmark$ & 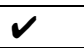 & $\mathrm{X}$ \\
\hline Sönmez 01 & $\mathrm{X}$ & $\mathrm{X}$ & $\checkmark$ & $\mathrm{X}$ & $\checkmark$ \\
\hline Bezostaja & $\mathrm{X}$ & $\mathrm{X}$ & $\checkmark$ & $\mathrm{X}$ & $\mathrm{X}$ \\
\hline
\end{tabular}




\section{DISCUSSION}

T. foetida and T. caries fungal pathogens are the major actors for common bunt disease [2]. This disease is very dangerous seedborne disease for wheats and causes heavy losses in yield quality and quantity [1-2, 6-5]. At present, Tilletia species can be effectively controlled using fungicide treated seeds, however, due to the distribution difficulties and high costs of the chemical treated seeds, use of pathogen resistant cultivars is preferred in most of the seed breeding programs world-wide [3,8]. Therefore, the known important bunt protection strategy is the use of partially or fully resistant wheat cultivars [5]. In this study, we focused on resistance genes $(b t)$ in wheat for development of resistant varieties against common bunt disease. The resistant gene data obtained using molecular SSR markers were compared with resistance rates in field studies. We obtained virulence rates of five T. foetida isolates against ten registered local wheat varieties (Sertak 52, Bolal 2973, Demir, Kutluk, Harmankaya 99, Pehlivan, Tosun Bey, 4-11, Sönmez 01, Bezostaja-1) and resistance of these wheat varieties against five $T$. foetida isolates. We determined five $b t$ genes $(b t-5, b t-8, b t-10, b t-11$ and $b t$ 12) in ten wheat varieties using PCR-based molecular markers (Table 5). Cota et al. (2010) performed some RAPD and SSR markers for $b t$ genes in wheat lines and cultivars come from NARDI (National Agricultural Research and Development Institute Fundulea, Romania). They obtained $790 \mathrm{bp}$ band for bt10 using RAPD UBC 196 primer, respectively $120 \mathrm{bp}, 160 \mathrm{bp}$ and $180 \mathrm{bp}$ bands for $b t 11, b t 10$ and $b t 8$ using Xgwm 114 SSR primers and 230 bp band for bt10 using Xgwm 633 SSR primers [21].

Studies about resistance genes in wheat until today are limited. Menzies et al. (2006) aimed the determination of the chromosomal location in wheat of the common bunt ( $T$. tritici and T. laevis) resistance gene Bt10. They tested a series of 50 wheat microsatellite markers were tested on DNA of the individual wheat lines and obtained 165 bp band for bt 10 gene using Xgwm 469 primers [20]. Wang et al. (2009) hybridized a resistant wheat variety (Blizzar) against common bunt in West Canada with sensitive variety (8405JC3C) [13]. They tested the obtained populations using Xgwm 374, Xgwm 264 and Xgwm 128 microsatellite markers and detected these markers locations on wheat 1BS chromosome. They reported that Xgwm 374 and Xgwm 264 markers be linked with bt12 gene [13].

\section{CONCLUSION}

The gene-for-gene interaction that exists between avirulence genes of the bunt pathogen and the individual host resistance genes accounts for the non-durable resistance of most cultivars. We observed that wheat varieties Kutluk and 4-11 possessing $b t-10$ and $b t 11$ genes are more resistant to disease in our field studies. In addition, it was founded that Kutluk have an extra gene as bt12. These two varieties were notified resistant in scientific literature. Although Sönmez 01variety includes only $b t 10$ and bt 12 genes, this variety is very resistant to disease in field. We determined Tosun Bey variety as sensitive alike literature. On the contrary, while Harmankaya99 was notified resistant in literature, this variety is sensitive against four $T$. foetida isolates according to our field data. It is interesting that both wheat varieties have same three resistance genes (bt-10,bt-11 and bt12). We also observed same three $b t$ genes in Kutluk, Tosun Bey and Harmankaya wheat varieties in contrast to their low response to the bunt disease in the field. This contrast case may be explained with dysfunctional mutant $b t$ gene forms. Though to observe positive result with PCR markers in some wheat varieties, resistance positions against disease should be confirmed with field data. Similarly, although Demir variety includes $b t 8, b t 10$ and $b t 12$ genes, it is not resistant against disease according to field results. We observed that bt10 and bt12 genes are synergistic in increasing of resistance against disease. Resistance genes served to select the virulent types from the pathogen population. Therefore, to know the prevalent races in a given area together with the non-prevalent races is essential for plant breeders. The non-prevalent races in the pathogen population is later predominate in response to the release of new resistance genes or new combinations of resistance genes. The results of our studies will contribute to breading strategies in fight against common bunt disease. 


\section{ACKNOWLEDGEMENTS}

The authors would like to thank Prof. Dr. Fahri ALTAY for advising and Aysel YORGANCILAR from Geçitkuşağ 1 Agricultural Research Institute (Eskişehir, Turkey) for providing of bunt isolates. This study was supported by The Basic Sciences Research Group of the Scientific and Technological Research Council of Turkey (TUBITAK-2209/A).

\section{REFERENCES}

[1] Matanguihan JB, Jones SS. A New Pathogenic Race of Tilletia caries possessing the broadest virulence spectrum of known races Online Plant Health Progress, 2011. doi:10.1094/PHP-2010-052001-RS.

[2] Yarullina LG, Kasimova RI, Kuluev BR, Surina OB, Yarullina LM, Ibragimov R I. Comparative Study of bunt pathogen resistance to the effects of fungicides in callus co-cultures Triticum aestivum with Tilletia caries Agricultural Sciences 5: 906-912, 2014.

[3] El-Naimi M, Toubia-Rahme H, Mamluk OF. Organic seed-treatment as a substitute for chemical seed-treatment to control common bunt of wheat European Journal of Plant Pathology 106: 433-437, 2000.

[4] Josefsen L, Christiansen KS. PCR as a tool for the early detection and diagnosis of common bunt in wheat, caused by Tilletia tritici Mycol. Res. 106: 1287-1292, 2002.

[5] Waldow F, Jahn M. Investigations in the regulation of common bunt (Tilletia tritici) of winter wheat with regard to threshold values, cultivar susceptibility and non-chemical protection measures Journal of Plant Diseases and Protection 114: 269-275, 2007.

[6] Dumalasová V, Bartoš P. Effect of Inoculum Doses on Common Bunt Infection on Wheat Caused by Tilletia tritici and T. laevis Czech J. Genet. Plant Breed. 44 (2): 73-77, 2008.

[7] Koprivica M, Jevtic R, Markovic ID. The Influence of Tilletia spp. inoculum source and enviromental conditions on the frequency of infected wheat spikes Pestic. Phytomed. 24: 185-196, 2009.

[8] Goates BJ. Identification of new pathogenic races of common bunt and dwarf bunt fungi, and evaluation of known races using an expanded set of differential wheat lines Plant Disease 96: 361-369, 2012.

[9] Lu ZX, Gaudet D, Puchalski B, Despins T, Frick M, Laroche A. Inducers of resistance reduce common bunt infection in wheat seedlings while differentially regulating defence-gene expression Physiological and Molecular Plant Pathology 67: 138-148, 2006.

[10] Goates BJ, Wilcoxson RD, Saari EE. "common bunt and dwarf bunt" Bunt and Smut Diseases of Wheat Concepts and Methods of Disease Management CIMMYT 19-30, 1996.

[11] Laroche A, Demeke T, Gaudet DA, Puchalscki B, Frick M, Mckenzie R. Development of the PCR marker for rapid identification of the $B t 10$ gene for common bunt resistance in wheat Genome 43: 217-223, 2000. 
[12] Fofana B, Humphreys DG, Cloutier S, McCartney CA, Somers DJ. Mapping quantitative trait loci controlling common bunt resistance in a doubled haploid population derived from the spring wheat cross RL4452xAC Domain Mol Breeding 21: 317-325, 2008.

[13] Wang S, Knox RE, DePauw RM, Clarke FR, Clarke JM, Thomas JB. Markers to a common bunt resistance gene derived from 'Blizzard' wheat (Triticum aestivum L.) and mapped To chromosome arm 1BS Theor. Appl. Genetics 119: 541-553, 2009.

[14] Ganal MW, Röder MS. Microsatellite and SNP markers in wheat breeding. In: Varshney RK, Tuberosa R. (Eds.) Genomics Assisted Crop Improvement: Genomics Applications in Crops 2: 1-24, 2007.

[15] Doyle JJ, Doyle JL. A rapid DNA isolation procedure for small quantities of fresh leaf tissue Phytochem. Bull. 19: 11-15, 1987.

[16] Ingold CT. The basidium of Tilletia and its evolution Mycologist 11(3): 98-100, 1997.

[17] Datta R, Singh H, Gupta VS, Ranjekar PK, Dhaliwal HS. Gene-for-gene relationship for resistance in wheat to isolates of Karnal bunt Neovossiaindica Plant Breeding 118: 362-364, 1999.

[18] Transitional Zone Agricultural Research Institute: Registered varieties. http://arastirma.tarim.gov.tr/gktaem/Menu/12/Tescilli-Cesitlerimiz.

[19] Directorate of Trakya Agricultural Research Institute: Registered varieties. http://arastirma.tarim.gov.tr/ttae/Link/1/Cesitlerimiz.

[20] Menzies JG, Knox RE, Popovic Z, Procunier JD. Common bunt resistance gene Bt10 located on wheat chromosome 6D. Canadian Journal of Plant Sciences 86:1409-1412, 2006.

[21] Cota LC, Pamfil D, Botez C, Grigoras M. Preliminary Studies on Microsatellite Marker Analysis of Resistance to Common Bunt in several Wheat Genotypes (Triticum aestivum L.)

Not. Bot. Hort. Agrobot. Cluj 38/2: 42-47, 2010. 